\title{
Women: Prepare to Lead Your Family Firm
}

\author{
Dr. Susan Laverick (House of Beaufort) \\ Elizabeth Bagnall (House of Beaufort)
}

KEYWORDS: Family Business, Women.

If you're reading this article, you may want to lead your family business someday but have not yet taken control of the direction your career is heading. Or perhaps you are experiencing some of those well-documented challenges that women have historically faced in businesses everywhere: invisibility as internal mediators and advisors, unconscious bias from inside and outside the firm, or skepticism if you've taken over the family firm from a man.

From our experience coaching women into leadership positions, we know it is never too early to lay the foundations for future success by taking control of your career - whether as a leader-in-waiting or as a daughter seeking a particular role in the generational succession process. We therefore begin this article with an illustrative example from our coaching portfolio and conclude with a strategy to help you to take control of your career.

\section{The Pharmaceutical Heiress}

Meet Jane, the daughter successor to a European pharmaceutical business. She had been closely involved with the business since her graduation with an MBA in Pharma eight years previously. Her father and the business founder planned to see her safely installed as CEO before retiring. So far, so good. Yet Jane faced a number of dilemmas: family tensions that followed her appointment; the need to manage a brother's altered expectations; the need to persuade the industry that she was not a "soft touch" after her father's more autocratic style; and finally, deciding how to honor his legacy while taking control on her terms.

Although the career constraints that Jane faced were unique to her situation, many of you may face similar challenges, perhaps even feeling that solutions are beyond your control. We will now introduce a three-part strategy to help you begin the process of overcoming career constraints. It involves examining key areas that you can influence, and that will lead you to taking control on your terms. You will need to consider:

Your ambition.

The network that will support it.

The biases that could thwart it.

\section{Articulating ambition, stress checking and setting goals}

You cannot take control of your career without first articulating your ambition -- and by the way, ambition is a positive quality so we can forget the societal norms that tell us otherwise.

Take a moment to think: what particular role do you passionately want to play in the family business? Start by writing your ideal job description, because the exercise will force you to reflect deeply on, and then to articulate, your ambition. Go beyond your comfort zone as you formulate ideas. Play devil's advocate with everything you are writing so that you can justify and defend your position.

\section{Stress Check}

It is essential to assess your strengths and scrutinize your weaknesses in order to maximize the value of your talents. What is your Achilles' heel? What do you deliberately avoid and why? Next, create an inventory of your unique core skills, talents and professional achievements. Acknowledging these skills, and how they can drive the business forward, is the first step to demonstrating that you can and should play a pivotal role in its future success.

\section{Set SMART goals \\ Creating SMART (specific, measurable, attainable, realistic and time bound) professional development goals will also help you to take control of your career. Remember that the ability to set clear goals, and to be accountable to them, is an essential leadership trait.}

Copyright $@ 2019$ The Authors. Entrepreneur \& Innovation Exchange is published at EIX.org. This is an open access article under the terms of the Creative Commons Attribution-NoDerivs License, which permits use and distribution in any medium, provided the original work is properly cited and no modifications or adaptations are made. View EIX.org Authorship Terms at https://eix.org/terms
FamilyBusiness 
Are these goals realistic? Will you be disciplined in achieving them? Don't forget that establishing a realistic timeline/time frame is vital for retaining control of momentum and to achieve progress.

\section{Analyzing and maximizing your network and exposure}

Approaching your network strategically will build your reputation and extend your influence in the industry. It will also enhance your authority and help increase the support needed to overcome some of the more negative forces at play on the road to leadership, including allusions to nepotism and the challenges of genderbased biases.

\section{Become a mentor and role model}

Much is written about the importance of finding a mentor, but we would suggest the value of becoming a mentor to a more junior woman in your industry. While offering invaluable support to those women who are encountering challenges that you have already navigated, a growing network of mentees will consolidate your reputation as a strong female role model in the sector.

\section{Advocate for yourself; extend your exposure}

Having identified your unique skills and talents, you need to learn to talk about them and what they are bringing to the business. Remember, you are the ambassador of your accomplishments; they will not speak for themselves. Writing articles, speaking as an expert at conferences, sitting on advisory boards and building a strong network will help you to achieve this.

\section{Analyze your network; increase your support}

Have you mapped out your network? Are you trying to build an influential profile by yourself, or do you have supporters who can help you? Remember that a strong network will connect you, advise you, support, inform and teach you, and advocate on your behalf. It is never too early to ensure your network is as strong as possible. Does it include members of the family business board, the advisory board, and external advisors/investors who can both advise you and advocate on your behalf? This network will be invaluable in demonstrating to others that your expertise and experience, rather than your last name, make you the best woman for the job.

\section{When biases become obstacles}

You may face biases in your leadership journey, including those mentioned in Ernest \& Young's 2016 research "The Next Generation Survey: The Female Perspective," such as gender stereotypes regarding skills and confidence in abilities within the family business. Perhaps the most important piece of advice we can give is to be scrupulously careful in the language you use to describe your achievements or leadership qualities. Agentic language - which tends to be used to describe men and includes terms like "forceful," "visionary," "entrepreneurial," "competitive," "strategic," "results-driven" - is the language more often associated with leaders and leadership. Communal language which tends to be used to describe female skills and includes "team-player," "peace-maker," "collaborative," "supportive," "helpful" - is less associated with leadership descriptors.

Be aware of how language shapes perceptions. When discussing your business achievements, consider adjusting your language and articulating your skills depending on the audience. Consider questioning/expanding the language used to describe what makes a great leader for your family business. Finally, let's return to our pharmaceutical heiress, Jane, and revisit some of those strategies we developed together to help her take control of her career.

\section{Solutions: A transition to leadership}

Back to basics: as the youngest and favorite child, Jane faced hostility, unfounded criticism and concerns about her management capabilities from a brother who had expected to succeed their father. To address these challenges, we went back to basics and encouraged Jane to articulate her ambition and the goals she needed to achieve to realize it. This reflective process increased Jane's confidence stepping into the role of CEO and helped her determine how best she could steer the business.

Addressing biases. Next, we listed the brother's criticisms and the biases they represented. Jane's decision to proactively confront each one enabled us to scrutinize her soft-skills and whether his judgment might be justified. Indeed, she did need to improve how she communicated, especially in managing difficult conversations and fine-tuning her negotiation skills. These were vital areas to master if she was to become the authoritative leader she aspired to be. 
Leveraging her network. One taunt from her brother lingered in Jane's mind: "The industry know you will be a soft touch after Papa." We reviewed her network and found people who could speak on her behalf about her accomplishments. By expanding her existing network, Jane is becoming known for her expertise and skill in the industry, not as the favorite daughter that a doting father had designated as his successor. While this all remains a work in progress, Jane has firmly taken control of her new role, on her terms.

\section{Conclusion}

Anna Wintour once noted that "people respond well to those who know what they want." Women can take control of their careers and become enormously empowered in the process, but they must first know what they want and be able to articulate their ambition boldy. So be strategic in your thinking and disciplined in your goals, and understand the key areas that you can influence. You should achieve the role that you so richly deserve. We wish you the very best of luck.

\section{References}

Ernest \& Young. The Next Generation Survey: The Female Perspective (2016).

Dr Susan Laverick and Elizabeth Bagnall are directors of House of Beaufort, an international consultancy with a dedicated platform for the professional empowerment of women. They are also authors of In Case of Emergency, Break the Glass: The Handbook of Critical Skills for Career Success, details of which can be found on their website, houseofbeaufort.com.

It is written for women, at whatever stages of their careers, providing practical strategies to help them overcome professional challenges.

\section{Read More}

Advice, Best Practices and Inspiration for Women Entrepreneurs(https://familybusiness.org/women)

Additional search terms: women, feminism, female founders, women business owners, glass ceiling, sexual discrimination, bias, opportunity, leadership skills, leadership skills for women, leadership challenges 